\title{
Education to Enhance Vietnamese Coastal Communities' Adaptive Capacity to Cope With Climate Change
}

\author{
Thi Huong Tra Nguyen
}

\section{Helen Boon}

\section{David King}

James Cook University

etropic 14.1 (2015): 111-122. http://www.reefandleaf.com.au/etropic.html \& http://www.jcu.edu.au/etropic

\begin{abstract}
Vietnam is highly vulnerable to the impacts of climate change, particularly in poor coastal communities. While external climate change projects have been conducted in some coastal provinces, including Ha Tinh, there is a lack of local education programs to enhance communities' awareness and adaptive capacity to cope with climate change. Therefore, a community education program is proposed to help Ha Tinh locals adapt to climate change. The aim of this paper is to present a brief literature review, including: identifying key concepts, overviewing global climate change, analysing climate change and climate change adaptation in Vietnam, as well as theoretical frameworks.
\end{abstract}

Key words: Climate change; Climate change education; Adaptation; constructivism; sustainable development

\section{Introduction}

In recent years, climate change has become such a global issue so many countries throughout the world have been paying a lot of time and attention to this problem. Climate change has affected all countries, whatever their level of development, but poor countries are more severely affected than developed countries because the poor countries do not have enough resources to cope with climate change.

Vietnam has more than 3,200km of coastline and approximately 3,000 islands both small and large (Boateng, 2009). With these characteristics, Vietnam is highly influenced by adverse climate change impacts and natural hazards (Asian Development Bank, 2009), especially in coastal zones. Studies from the Ministry of Natural Resources and Environment (MONRE) suggested that Vietnam is among the countries most susceptible to hazards, natural disaster events and climate change impact (MONRE, 2008). The Ministry of Natural Resources and Environment also found that in coastal areas of Vietnam, $70 \%$ of the population is living with the threat of sea level rising and other natural hazard events of climate change. According to the World Bank (2010), if sea level rises about 1m, approximately $10 \%$ of population will be directly affected by this and may need to relocate or adapt their lifestyles and economy. 
Ha Tinh (study site) has $137 \mathrm{~km}$ of coastline in North Central Vietnam, which is exposed to severe impacts from strong waves due to monsoon variations and other natural hazards such as typhoons, storms, floods, drought, sea level rise and inundation (MORNE, 2008). Thinh Loc commune is located on the eastern coast of Ha Tinh with little infrastructure and community residents have been suffering from climate change. Climate change has caused many disadvantages in social and economic terms (Nguyen, 2011). Nguyen (2011) showed that due to natural disasters, Thinh Loc village's crop productivity decreases while insect and plant diseases increase. Environmental pollution affects community health and threatens all life. Unemployment and unexpected local migration are also severe results from climate change. Damage to infrastructure, transport systems and housing in the communities is also an urgent problem. With the above issues in mind, building and conducting sustainable strategies within the community of Thinh Loc to address with climate change is extremely necessary. Some solutions have been implemented by both local government and community members but they are temporary and unsustainable. This is due to a lack of supported resources from both outside and inside the community. Thus, this research will propose a sustainable solution to enhance the community's adaptive capacity to address with climate change. Improving local residents' awareness and adaptive capacity through conducting a climate change education program will be one of the most helpful supports to cope with climate change in Thinh Loc community.

\section{Literature Review}

\section{Key Definitions}

\section{Climate change}

Climate change was recognized as a global environmental problem for the first time in the late 1970s. The American climatologist James Hansen developed the hypothesis that burning fossil fuel over a long period of time would heat the Earth. In the first World Conference on Climate organized in 1979 in Geneva, scientists asserted that human activity could cause climate change which would cause suffering to both humans and the environment. Then, from the 1980s, international organizations and developed countries invested a huge amount of money in research to explore the hypothesis of climate change (Dimento \& Doughman, 2007). According to Healey (2009), the simplest way to understand climate change is that it is a global issue that affects us all. Changes in climate patterns mean that extreme weather events such as heat-waves, floods, storms, droughts and bushfires will become more frequent, more widespread or more intense. The Intergovernmental Panel on Climate Change (IPCC) referred to climate change as any change in climate over time, which could be caused by natural variability or damage from human activities (Levina \& Tirpak, 2006). On the other hand, the United Nations Framework Convention on Climate Change (UNFCCC) defined climate change as a change of climate resulting directly or indirectly from human activity.

\section{Adaptation}

Adaptation to climate change is one of the most important concepts in this research.

According to the IPCC, adaptation is a change of either natural or human systems in response to climate, weather or its effects, which cause harm or destroy beneficial opportunities. Types of adaptation are varied, including anticipatory and reactive adaptation, as well as autonomous and planned adaptation (Levina \& Tirpak, 2006).

Meanwhile, the United Kingdom Climate Impact Program argues that adaptation is a process or results of a process which causes a mitigation of disadvantages from climate change (UKCIP, 2003 cited in Levnina and Tirpak, 2006). Similar to UKCIP, Smit and Wandel (2006) mention adaptation in the context of human dimensions of global change as a process, 
action, or outcome by a household, group, community, sector, region, country, which helps better to cope, manage or adjust to some changing condition, stress, hazard, risk, or opportunity (Smit \& Wandel, 2006).

\section{Global Climate Change}

Climate change is an unavoidable reality (Dimento \& Doughman, 2007). According to Alley (2007 cited in Dimento and Doughman, 2007), the global surface temperature increased $0.74^{\circ} \mathrm{C}\left(1.33^{\circ} \mathrm{F}\right)$ in the twentieth century. It also provided a 2007 prediction from the IPCC that by 2100 average surface temperature will rise between $1.8^{\circ} \mathrm{C}$ to $4.0^{\circ} \mathrm{C}\left(3.4^{\circ} \mathrm{F}\right.$ to $\left.7.2^{\circ} \mathrm{F}\right)$. The IPCC has reported growth in the frequency, intensity, and duration of heatwaves during the past century (Meehl, Arblaster, \& Tebaldi 2005 cited in Dimento \& Doughman, 2007). Sea levels are also predicted to rise. Alley (2007) predicted that by 2100 global sea level will surge from 0.28 to 0.43 metres ( 0.92 to 1.40 feet). The IPCC also warned that if the Greenland ice sheets are melted the total sea level rise will be 7 meters ( 23 feet) by the end of the century. Sea level rise is one of the chief reasons for the rising incidence of floods and erosion, the decrease in wetlands and mangroves, and accelerating inundation of coastland (Houghton et al., 2001a cited in Dimento \& Doughman, 2007). It is expected that tropical surface ocean temperature will go up $1^{\circ} \mathrm{C}-2.5^{\circ} \mathrm{C}\left(1.8^{\circ} \mathrm{F}-4.5^{\circ} \mathrm{F}\right)$ over the next one hundred years. Due to that warmer ocean water, waves will get stronger and more devastating tropical storms may occur in the near future (Knutson \& Tuleya, 2004).

\section{Climate Change and Climate Change Adaptation in Vietnam}

Vietnam is affected by two tropical monsoon climatic regimes and mostly influenced by natural disasters related to these two climatic regimes such as storm surges, monsoon rains, floods, typhoons, and EL- Niño conditions (Boateng, 2009). According to Imaura and To (1997, citied in Boateng 2009), Vietnam continues to experience typhoons/cyclones, storm surges, and floods with substantial damage to environmental, economic, and social structures. A variety of international and domestic sources illustrate that Vietnam is both very vulnerable and heavily exposed to the risks of increasing weather variability and climate change. Many studies point out that climate change is strongly believed to result in socio - economic impacts in Vietnam, particularly upsetting poverty reduction efforts (Bruun \& Casse, 2013).

Research on 'Climate change, environmental degradation and migration' was conducted in three less developed countries: Egypt, Mozambique and Vietnam (Warner et al., 2010). In all three countries, national governments have used resettlement and relocation as an adaptation strategy to cope with climate change. The Mekong delta area in Vietnam was chosen as a case study to examine the perspective of environmental change and immigration due to a large percentage of the rural population being directly dependent on the area for their livelihood (Adger, 2001 cited in Warner et al., 2010). This area is especially vulnerable because flooding destroys their crops, which triggers a decision to migrate elsewhere to find an alternative livelihood during the flood season. This affects agricultural productivity and labour sources in the Mekong River Delta as well as the total national rice export of Vietnam as $90 \%$ of Vietnam's total national rice export comes from the Mekong River Delta.

To manage the problem above, the Vietnamese central government has conducted a program known as 'Living with flood' to relocate people living in vulnerable zones along river banks. It is expected that approximately 20,000 landless and poor households will be targeted for relocation by 2020. Furthermore, changing livelihood schemes are implemented to save local people. An example is the change from rice to fishery-based jobs. Migration and alternative 
livelihoods are considered to be reasonable adaptation strategies to cope with climate change in the Mekong River Delta. However, this leads to changes in social structure and the agricultural culture of the local people. This may cause stress, psychological and mental health impacts during and after flooding. Therefore, it is very important to relocate people to places with similar customs, lifestyle and agricultural culture to mitigate psychological stress. In the proposed study site, Ha Tinh province, some studies have been conducted about climate change. First of all, the project conducted by MONRE and UNDP (United National Development Program) in 20009 named 'Building resilience: Adaptive strategies for coastal livelihoods most at risk to climate change impacts in Central Vietnam. The research showed that saline intrusion, erosion, flood, storm, typhoon, drought, and sea level rise are common climatic variability in Central Coastal Vietnam. These phenomena are becoming prolonged, more extreme in fluctuations, and continue to increase. Then, researchers suggested key adaptations for both government and resident's livelihood which is under threat of severe change due to these climatic hazards. Specifically, it is necessary to improve environmental governance and provide more equitable support from local governments. Next, migration and relocation are considered as a livelihood diversification for local communities. Finally, allotting budgets to build hard and soft infrastructure will be essential to minimize serious impacts and protect human from natural disasters (Truong, 2009).

Nguyen (2009) reviewed socio-economic conditions, climate change and natural disasters and analyzed impacts of climate change to suggest adaptation plans to cope with climate change in Ha Tinh province. According to Nguyen (2009), to cope with climate change, governments and local government planned to prevent potential effects of climate change in all socioeconomic sectors: water resource, agriculture, forestry, industry, energy, transport and medical care in Ha Tinh province. Some of the climate change adaptation policies and measures in agriculture, health care and water resources were also mentioned in this report. In terms of water resources, planners suggested building dams and reservoirs for storing water, flood control and to save water supply for use in the dry season. Improving the irrigation and drainage systems and expanding sea dykes to prevent sea level rise were mentioned as important adaptation strategies. In the agricultural field, several methods were suggested to respond to climate change, with rechecking and regulating plans of crop schedules, irrigation and drainage activities to accommodate potential climate change considered as particularly important methods. In health care strategies, it is important to improve people's awareness about domestic sanitation through the Clean Water and Environmental Sanitation program and to improve health care services and facilities in the regions to prevent epidemic diseases due to climate change.

Another project from the Ministry of Natural Resource and Environment (2009) was conducted in four coastal communities in Ha Tinh and Ninh Thuan province with the purpose to provide an assessment of livelihood adaptation and available response measures to mitigate the impacts of climate change related to natural hazards. The project suggested some adaptation measures to cope with climate change to be implemented by the Ministry of Natural Resources and Environment such as: maintaining and developing irrigation systems; changing crop and livestock systems to be more resilient to drought; applying modern technology in agriculture such as effective and efficient irrigation systems; developing appropriate livestock management plans; and establishing the sea dyke system in coastal areas.

Generally, most studies on climate change in both overseas and Vietnam focus on the regional, government, powerful private enterprise levels, while research of climate change at 
the individuals, household and community levels has been neglected. Moreover, adaptation options to climate change impacts have often been developed by outsiders whereas it is the local communities that have been directly influenced by climate change impacts. In other words, a local voice has not been involved in the process of developing strategies to adapt to climate change impact in these studies. This was also identified in the Program of Vietnam Child- Centred Climate Resilience conducted in 2012 supported by five international organizations. This project also confirmed that there was a generally a low level of awareness of climate change and locality - relevant effective adaptation options in several previous programs (CRD et al., 2012). Therefore, there is an urgent need to conduct an educational program at commune level to enhance knowledge and change behaviour to cope with climate change. Thus, local voice will be one of the strongest capacities to address with climate change. Some climate change education programs have been applied in Vietnam in a few schools and communities but these programs are still limited (CRD et al., 2012). Therefore, it is necessary to fill this gap in climate change research in Vietnam, especially in the study site: Thinh Loc commune, Loc Ha district, and Ha Tinh province.

\section{A Climate Change Education Program}

A climate change education program is identified as an essential intervention to enhance Vietnamese coastal communities' adaptive capacity for coping with climate change.

\section{The necessity for climate change education in Vietnam}

Climate change education is not necessarily new (Vize, 2012). Vize (2012) showed that awareness programmes on climate change have been conducted in many areas across the Pacific targeting several groups. However, climate change education in this area faces many problems. Firstly, budgets are not large, although Pacific governments invest in education; the majority of money is spent on teachers' salaries and school infrastructure. Secondly, the means of communication in some countries are poor as officials have limited access to the Internet, email and other modern communicational technologies. Thirdly, the climate change curriculum is competing with other programs such as physical education, human rights or democracy and peace. Furthermore, climate change education normally focuses on information rather than skills. In his research Vize (2012) found it is essential to balance the approach between knowledge, attitudes and behaviour.

Bangay and Blum (2010) argued that although there is an increasing recognition of the role of education in climate change, the capacity of education to contribute to adaptation and mitigation is limited. The writers suggested that the potential of the variety of educational methods including formal and non- formal education, and from primary until tertiary as well as adult education, must be highlighted (Bangay \& Blum, 2010). The paper also discussed the importance of climate change education and claimed that climate change education should be a main priority for international development, especially in developing countries. This is due to higher temperature, inconsistent rainfall, more dependence on the agricultural livelihood, and the cost of building essential infrastructure (Bangay \& Blum, 2010).

Preneau, Khattabi, and Demers (2010) argued that climate change education for mitigation is not easy to conduct. According Preneau et al., (2010) also argued that previous studies on climate change have been faced with several challenges. Firstly, climate change concepts are often misunderstood. Secondly, many people do not recognize that climate change will affect their lives or climate change continues to happen gradually and slowly (Pruneau et al., 2010). These researchers identified cognitive challenges; social and psychological challenges; as well as behavioural challenges in climate change education. The goal of climate change education is to mitigate and adapt with climate change, but a number of people believed that 
this issue will be solved quickly (Owen, 2005; Patchen, 2006 cited in Pruneau et al., 2010). Furthermore, people claimed that governments and industries must take complete responsibility in solving and confronting climate change. There was also a belief that climate change and natural disasters are natural phenomena, thereby humans cannot control and solve them. In regards to human behaviour, a major challenge continues to be overconsumption, which is one of the largest causes of climate change. Changing consumption behaviour of the human race is difficult because people have instinctive needs to have fun, gain power, receive exciting stimuli and be loved (Seider, 1998 cited in Puneau et al., 2010).

Although faced with the several challenges above, many researchers in the World Conference on Disaster Reduction (2005) asserted that education is still an important element for confronting natural disasters and obtaining a sustainable development (Shaw \& Rouhban, 2005). In Vietnam, especially in the study site- Ha Tinh province, which is identified as one of the poorest provinces, a large percentage of the population works in the agricultural and aquaculture sectors. Their livelihood is totally dependent on climatic conditions so that climate change is devastating to this region. Obtaining basic knowledge on climate change, mitigation and adaptation to cope with natural disasters is important for these local residents in the study site. Meanwhile, numerous climate change projects have not provided enough information on climate change for local residents in this area. As well, designing and applying a formal curriculum at school will face many challenges because it is difficult to insert climate change curriculum into an academic syllabus already established for all schools. Overall, designing and applying a community education program to assist in coping with climate change is a key solution to support the study site's citizens in preparing, preventing and adapting to annual natural hazards.

\section{Theoretical Frameworks}

\subsection{Climate change education for sustainable development (CCESD)}

Worldwide, there are a variety of frameworks in climate change education to use when adapting and mitigating natural disasters for sustainable development. However, a holistic model for climate change education for sustainable development (CCESD) developed by Sellby and Kagawa (2012) is the most appropriate theory for developing a climate change education program in Vietnam. Sellby and Kagawa (2012) argued that in the past climate change education was focused on the causes of climate change rather than understanding the destructive behaviour of humans and the necessity to educate for change. Moreover, climate change education focused on physical and natural science where it is thought that technical and scientific frameworks can address climate change (Cschreiner et al., 2005: Selby 2010: 38 cited in Kagawa \& Selby, 2012). Recently, researchers have shown that social and personal values affected by climate change should be the centre of climate change education (Adam 2009:14; Selby 2010 cited in Kagawa \& Selby 2012). UNESCO and United Nations Environment Programme (2011) strongly emphasized the importance of improving the knowledge and abilities of all ages in order to build strategies to cope with climate change. As a result, Selby and Kagawa (2012) have developed a new model for climate change education. The educational model illustrates the understanding and attentiveness aspect in creating clear awareness to climate change. This is necessary because of the threats of climate change to a large population as well as widespread misconceptions about climate change. At the same time, the mitigation aspect is about identifying the causes of climate change and the development of knowledge, skills and actions for individuals and society. Finally, the adaptation aspect involves improving the knowledge, skills and dispositions to better face the looming climate impacts. It is vital that the adaptive education combine technical strategies and indigenous knowledge. The three dimensions are complementary and allow for the continuing dialectic between engagement and reflection that is the foundation for 
transformation. This model is predicted as a new worldview and will assist with a more sustainable future to cope with climate change (Selby \& Kagawa, 2012)

\subsection{Awareness Behaviour Intervention Action (ABIA)}

In terms of climate change adaptation, researchers in the United Kingdom suggested the use of a decision support framework to encourage environmentally responsible behaviour: the Awareness Behaviour Intervention Action (ABIA) which encourages both individual and community engagement in solving of sustainability issues (Hayles, Dean, Lappin, \& McCullough, 2013). According to the authors the goals of the ABIA framework are to encourage and facilitate participants to create new sustained environmentally responsible habits based on their own informed decisions (Hayles et al., 2013). This framework has been designed to work with four stages, including:

1. Awareness: Participants are given questionnaires to gather information on their understanding of natural disasters.

2. Behaviour: Identifying actual behaviours of participants by in-depth interviews.

3. Intervention: Giving educational material and tools such as focus groups, literature, and media to support behavioural change.

4. Action: Providing opportunities for individuals, families and the community to reflect and evaluate how their actions change post- intervention.

This model could be extremely useful in orientating a research design for my project. Following the four steps above as a guideline could help achieve the study's goals.

\subsection{Constructivism}

To conduct the educational intervention program, the theory of constructivism will be applied to support learning and teaching in the community. Constructivism states that learners build their own knowledge and understanding of the world through their experience and reflecting on that experience (O’Donnell et al., 2012). In the classroom, the constructivist view means that learners are encouraged to use active ways to create knowledge and understanding, and then reflect upon their thoughts. As well, the constructivist teachers ensure their students' preexisting concepts are examined and questioned; then they guide them to address and build on new knowledge (O’Donnell et al., 2012).

Under the constructive teacher's encouragement, students use their previous experiences and then gradually develop their abilities to integrate new information. This method brings numerous benefits for learners. First, learners learn more and enjoy learning more because they are actively involved rather than passive listeners. Second, constructivism focuses on thinking and understanding rather than memorization. Third, by active learning and thinking, the students are more likely to maintain, transfer, and apply their knowledge to real life. Finally, constructivism enhances learners' cooperation and exchange of ideas, which is essential in making successes in real life (O'Donnell et al., 2012).

The theoritical frameworks mentioned above will orient the climate change education program in the coastal commune, Thinh Loc village. A system of knowledge, mitigation, and adaptation for coping with climate change will be the foundation for this education program. The program will be implemented through 4 stages: a) identifying the learner's awareness, b) observing behaviour of households, c) conducting intervention by training, teaching, multiple campaigns, and d) evaluating local resident's awareness and behaviours. Community residents such as farmers, fishermen, school children, teachers, and local government staff 
will be targeted through constructivist approach. It is anticipated that several fieldtrips, quantitative and qualitative methods, as well as media tools will be used when conducting and assessing of the program.

\section{Conclusion}

It is clear that environmental education for the community is becoming a common trend and has potential benefits for a large population. Climate change education is completely suitable to be applied in Vietnam rural areas because of the following reasons:

Firstly, each person and household has strong and close relationships with others in their community (Nguyen, 2011), as they occasionally plant fields and catch fish together, thereby meeting and exchanging information, as well as making conversation are regularly amongst households. This could be a great advantage for transferring knowledge from education programs to local residents by both formal and informal communications.

Secondly, by using and implementing media campaigns such as community audio, posters, pictures and other visual tools are the nature of the community is best addressed (Nguyen, 2011). According to Nguyen (2011) the Vietnamese communes are closed-villages due to limited space and cultural history. Therefore, all media programs are attractive to the local residents.

Thirdly, in rural areas, especially in poor and traditional communities, the extended family (there are many generations living in one household) accounts for the majority of the population (Le et al., 2012). This is thought to be highly effective for the transfer of knowledge between generations.

Finally, Thinh Loc commune owns public centres such as a flea market, hamlet houses, and a commune cultural house which local residents visit regularly to share experience and difficulties in their life with neighbours, friends, as well as local government officials. The habit of visiting these commune houses could be a potential opportunity to apply and conduct a climate change education program. In conclusion, with community characteristics analysed above, designing and conducting a climate change education program is vital in order to fill the gap from previous projects as well as meet urgent demand for both local residents and local governments in the study site.

\section{Works Cited}

Anderson, A. (2012). Climate Change Education for Mitigation and Adaptation. Journal of Education for Sustainable Development, 6(2), 191-206. doi: 10.1177/0973408212475199

AONTAS (The Irish National Association of Adult Education. (2004). Community education 2004. Retrieved from: http://www.aontas.com/pubsandlinks/publications/communityeducation-2004/

Abery, N. W., V. H. Nguyen, et al. (2009). Perception of climate change impacts and adaptation of shrimp farming in Ca Mau and Bac Lieu, Vietnam: Farmer focus group discussions and stakeholder workshop report. Retrived http://webcache.googleusercontent.com/search?q=cache:Yy3eoCzbpCoJ:library.enaca .org/emerging_issues/climate_change/2010/aquaclimate-report-2010annex10.pdf $+\& \mathrm{~cd}=1 \& \mathrm{hl}=\mathrm{en} \& \mathrm{ct}=\mathrm{clnk} \& \mathrm{gl}=\mathrm{vn}$ 
Ashtiany, M. G. (2005). Educational aspects of disaster management. Paper presented at the World Conference on Disaster: Reducation Proceeding of the Thematic session on Education for sustainable development, Japan. Retrieved from unesdoc.unesco.org/images/0015/001590/159067eo.pdf

Bangay, C., \& Blum, N. (2010). Education responses to climate change and quality: Two parts of the same agenda? International Journal of Educational Development, 30(4), 359-368.

Beniston, M. (2010). Climate change and its impacts: growing stress factors for human. International Review of the Red Cross 92(879).

Boateng, I. (2009). Spatial planning and climate change adaption in coastal regions: the case of Vietnam: proceedings of the International Federation of Surveyors 7th Regional Conference 2009 - Spatial Data Serving People: Land Governance and the Environment - Building the Capacity. In: 7th FIG Regional Conference: Spatial Data Serving People: Land Governance and the Environment - Building the Capacity, 2009-10-19 - 2009-10-22, Hanoi.. Retrieved from http://eprints.port.ac.uk/3847/

Brounwer, R., Akter, S., Brander, L., \& Haque, E. (2007). Socioeconomic vulnerability and adaptation to environment risk: a case study of climate change and flooding in Bangladesh. Journal of Rish Analysis, 27(2), 313-326.

Brown, T. J., Hall, B. L., \& Westerling, A. L. (2004). The Impact of Twenty-First Century Climate Change on Wildland Fire Danger in the Western United States: An Applications Perspective. Journal of Climatic Change, 62(1), 365-388.Bruun, O., Casse, T. (2013). On the Frontiers of Climate and Environmental Change Vulnerabilities and Adaptations in Central Vietnam. Dordrecht : Springer Berlin Heidelberg.

Brooks, J. G. (1999). In search of understanding: The case for constructivist classrooms: ASCD

CRD, AID, A., Children, S. t., Plan, Learn, L., \& Connservancy, T. N. (2012). Vietnam Child - Centred Climatic Resilience Program. Retrieved from http://aid.dfat.gov.au/Publications/Pages/sca-ccag-design.aspx

Dimento, J. F. C., \& Doughman, P. (Eds). (2007). Climate change: What it means for Us, Our children, and Our grandchildren. London, England: The MIT press.

Do, Q.T., \& Iyer, L. (2004). Rural Vietnam in Transition. Retrieved from http://webcache.googleusercontent.com/search?q=cache:dGah6LGIrfwJ:www.researc hgate.net/publication/228759642_Rural_Vietnam_in_Transition/file/5046351d5e8549 a9b1.pdf $+\& \mathrm{~cd}=4 \& \mathrm{khl}=\mathrm{en} \& \mathrm{ct}=\mathrm{clnk} \& \mathrm{gl}=\mathrm{vn}$

Few, R., Pham, G., \& Bui, T. (2004). Living with floods: health risks and coping strategies of the urban poor in Vietnam. Retrieved from http://webcache.googleusercontent.com/search?q=cache:gllJlnSvlhwJ:https://www.ue a.ac.uk/polopoly_fs/1.19249!study\%2520reportfinal.pdf+\&cd=1\&hl=en\&ct=clnk\&gl $=\mathrm{vn}$

Jacobs. S. (2008). Doi Moi and its Discontents: Gender, Liberalisation, and Decollectivisation in Rural Viet Nam. Journal of Workplace Rights 13(1), 17-39.

Hayles, S. C., Dean, M, S., Lappin. A., \& McCullough, E. J. (2013). Climate change adaptation: A decision support framework to encourage environmentally responsible behaviour. Journal of Smart and Sustainable Built Environment, 2(2), 192

Healey, J. (2009). The changing climate change, Issues in society, p. 44.

Nguyen, Q. T. (Ed). (2008). Contemporary Vietnam and Republic of Korea: A Glimpse from both sides. Hanoi: Vietnam National University Publishers.

Hoang, B. T. (2009). Rural employment and life: challenges to gender roles in Vietnam's agriculture at present. Retrieved from 
http://webcache.googleusercontent.com/search?q=cache:JFIwlUTtTZIJ:zunia.org/post /rural-employment-and-life-challenges-to-gender-roles-in-vietnams-agriculture-atpresent $+\& \mathrm{~cd}=3 \& \mathrm{hl}=\mathrm{en} \& \mathrm{ct}=\mathrm{clnk} \& \mathrm{gl}=\mathrm{vn}$

Kagawa, F., \& Selby, D. (2012). Ready for the Storm: Education for Disaster Risk Reduction and Climate Change Adaptation and Mitigation. Journal of Education for Sustainable Development, 6(2), 207-217.

Kameyama, Y., \& Sari, A. P. (2008). Climate Change in Asia: Perspectives on the Future Climate Regime. Retrieved from

http://webcache.googleusercontent.com/search?q=cache:QkvxyhjHDt0J:archive.unu.e du/unupress/samplechapters/Climate_change_in_Asia_web.pdf $+\& c d=1 \& h l=e n \& c t=c \operatorname{lnk} \& g l=v n$

Kawata, Y. (2005). Transfer Live Lessons of Catastrophic Disaster. Paper presented at the World conference on disaster reduction: Proceedings of the thematic session on education for sustainable development, Japan. Retrieved from http://webcache.googleusercontent.com/search?q=cache:kKrKsVRP7lAJ:unesdoc.une sco.org/images/0015/001590/159067eo.pdf+\&cd=1\&hl=en\&ct=clnk\&gl=vn

Knutson, T. R., \& Tuleya, R. E. (2004). Impact of CO2-induced warming on simulated hurricane intensity and precipitation: Sensitivity to the choice of climate model and convective parameterization. Journal of Climate, 17(18), 3477-3495.

Lai, T. (2008). Farmer, Rural and Agriculture- Issues setting up. Hanoi: Knowledge Publishing House.

Lam, S., Tran, B., \& Le, N. (2006).Livelihood, vulnerability and local adaptation strategies to natural disasters in Huong river basin. Retrieved from http://webcache.googleusercontent.com/search?q=cache:Wu3gPhAtYHAJ:www.nlcap .net/fileadmin/NCAP/Countries/Vietnam/032135.0503xx.VN.CON01.Output6.v1.pdf $+\& \mathrm{~cd}=1 \& \mathrm{hl}=\mathrm{en} \& \mathrm{ct}=\mathrm{clnk} \& \mathrm{gl}=\mathrm{vn}$

Le, M. C., Nguyen, T., \& Pham, H. T. (2012). Social- economic change in K'Ho community (Lac Duong, Lam Dong, Vietnam). Dalat University. Dalat University.

Levina, E., \& Tirpak, D. (2006). Adaptation to climate change: Key terms: Organisation for economic co-operation and development (OECD). Retrieved from http://webcache.googleusercontent.com/search?q=cache:GIMOF4uvMO4J:www.oecd .org/env/cc/36736773.pdf+\&cd=1\&hl=en\&ct=clnk\&gl=vnMcFarling, \& Lee, U. (2004, November ). Climate change accelerating, report warns. Los Angeles Times.

McLeman, R., \& Smit, B. (2006). Migration as an adaptation to climate change. Journal of Climatic Change, 76(1-2), 31-53.

McLoghlin, L. (2004). The role of community education in developing environmentally sustainable cities. Retrieved 8/1, 2014, from https://www.google.com.au/\#q=the+role+of+community+education+in+developing+e nvironmentally+sustainable+cities.

MONRE. (2008). National target program to respond to climate change. Ha Noi: Ministry of Natural Resourse and Environment. Retrieved from http://webcache.googleusercontent.com/search?q=cache:umwGVXZrsfAJ:www.isgm ard.org.vn/VHDocs/NationalPrograms/NTP\%2520RespondtoClimateChange.pDF+\&c $\underline{\mathrm{d}=4 \& \mathrm{hl}=\mathrm{vi} \& \mathrm{ct}=\mathrm{clnk} \& g \mathrm{l}=\mathrm{vn}}$

Nair. (2009). Climate change: societal impacts and curren policies and adaptation strategies in India. Journal of Climate change: Global risks, Challenges and Decisions, 6, 29-31.

Ngo, T. P. (2006). Social changes in vietnam rural area as the result of agriculture land use purposes transition. Hanoi: Vietnam National University publishers. 
Nguyen, T. (2008). Jobs for laborers during the transfer of agricultural land use purpose. Journal of Communist, 786, 72-75.

Nguyen, T. H. T. (2011). Climate change impacts and adaptation strategies for farmers in the coastal zones in Vietnam: A case study in Thinh Loc commune, Loc Ha district, Ha Tinh province. (Master), James Cook, James Cook University.

Nguyen, T. H. T., Pham, H. T., Luong, T. T. T. (2012). Social impacts of climate change in Vietnam and some countries. Social science information review 6(2), 37-46

O'Donnell, Dobozy, Bafrtlett, Bryer, Reeve, \& Smith. (2012). Educational Psychology. Australia: John Wiley \& Sons Astralia, Ltd.

Pingali, P. L., \& Xuan, V.-T. (1992). Vietnam: Decollectivization and rice productivity growth. Journal of Economic Development and Cultural Change, 40(4), 697-718.

Pittock, A. B. (2005). Climate change: turning up the heat. Australia: CSIRO Publishing.

Poster, C., \& Kruger, A. (1990). Community education in the western world. New York: Routledge.

Potter, G. (2009). Environmental Education for the 21st Century: Where Do We Go Now? Journal of Environmental Education, 41(1), 22-33. doi: 10.1080/00958960903209975

Pruneau, D., Khattabi, A., \& Demers, M. (2010). Challenges and Possibilities in Climate Change Education. Online Submission. Retrieved from http://eric.ed.gov/?id=ED514727

Sadowski, M. (2008). An approach to adaptation to climate changes in Poland. Climatic Change, 90(4), 443-451.

Shaw, R., \& Rouhban, B. (Eds) (2005). World conference on disaster reduction: Processing of the thematic session on education for sustainable development: Towards effective disaster reduction and enhancing human security. Japan. Retrieve from http://webcache.googleusercontent.com/search?q=cache:kKrKsVRP7lAJ:unesdoc.une sco.org/images/0015/001590/159067eo.pdf+\&cd=1\&hl=en\&ct=clnk\&gl=vn

Smit, B., \& Wandel, J. (2006). Adaptation, adaptive capacity and vulnerability. Global Environmental Change, 16(3), 282-292.

Son, D. K. (2008). Agriculture, Farmers, Rural in Vietnam: Today and Tomorow. Hanoi: The National Political Publishing House.

Sovacool, B. K., D'Agostino, A. L., Rawlani, A., \& Meenawat, H. (2012). Improving climate change adaptation in least developed Asia. Journal of Environmental Science and Policy, 21, 112.

Srinivasan, J., \& Hunt, J. (2011). Climate change in Asia. Journal of Curent Science (Bangalore), 101(10), 1269-1270.

Suwa, S. (2005). Activities to create the new trend of the disaster mitigation education by the students of the environment and disaster mitigation course of Maiko High School. Paper presented at the World conference on disaster reduction: Proceedings of the thematic session on education for sustainable development Japan. Retrieved from http://webcache.googleusercontent.com/search?q=cache:kKrKsVRP7lAJ:unesdoc.une sco.org/images/0015/001590/159067eo.pdf+\&cd=1\&hl=en\&ct=clnk\&gl=vn

Tobias, R. (1992). Defining non-formal and community education. New Zealand Journal of Adult Learning, 20(1), 77-92.

Tran, D. T., \& Nguyen, V. N. (2000). Social changes in Ho Chi Minh city's suburb under urbanizational pressure. Journal of Sociology, 69(1).

Tran, D. T., Saito, Y., Dinh, V. H., Nguyen, V. L., Ta, T. K. O., \& Tateshi, M. (2003). Regimes of human and climate change impacts on coastal changes in Vietnam.Journal of Regional Environmental Change, 4(1), 49-62. 
Tran, T. T., \& Nitivattananon, V. (2011). Adaptation to flood risks in Ho Chi Minh City, Vietnam. International Journal of Climate change Strategies and Management, 3(1), 61-73.

Truong, T. X. (2003). Some economic- social changes in Hong river rural area. Journal of Sociology, 3(83).

Truong, M. T., Ellis, J., A., \& Nguyen, T., T. (2009). Building resilience: Adaptive strategies for coastal livelihoods most at risk to climate change impacts in Central Vietnam. Hanoi, Vietnam: MONRE and UNDP. Retrieved from http://www.seachangecop.org/node/2762

Tuan, N. D. A. (2006). Agricultural Surplus and Industrialization in Vietnam Since the Country's Reunification. Retrieved from: repub.eur.nl/pub/32606/90-423-03034_DOK[1].pd

Vaughan, C., Gack, J., Solorazano, H., \& Ray, R. (2003). The effect of environmental education on schoolchildren, their parents, and community members: A study of intergenerational and intercommunity learning. The Journal of Environmental Education, 34(3), 12-21.

Vize, S. (2012). Using Education to Bring Climate Change Adaptation to Pacific Communities. Journal of Education for Sustainable Development, 6(2), 219-235.

Vo, V. V. (2011). Rural People's Livelihoods-A Case Study in a Commune at Mekong Delta, Vietnam. International Journal of Environmental and Rural Development 2-1.

Wang, J. X., Huang, J. K., \& Yang, J. (2014). Overview of Impacts of Climate Change and Adaptation in China's Agriculture. Journal of Integrative Agriculture, 13(1), 1-17. Warner, K., Hamza, M., Smith, A. O., Renaud, F., \& Julca, A. (2010). Climate change, environmental degradation and migration. Journal of Nat Hazards, 55, 689715.

Watson. (2001). Human development and climate change impact. Retrieved from http://webcache.googleusercontent.com/search?q=cache:mSKSkaOOXZ8J:www.nieh s.nih.gov/research/programs/geh/climatechange/health_impacts/human_developmenta l/index.cfm $+\& \mathrm{~cd}=3 \& \mathrm{hl}=\mathrm{en} \& \mathrm{ct}=\mathrm{clnk} \& \mathrm{gl}=\mathrm{vn}$ 